\title{
ANALISIS PELANGARAN MAKSIM KESOPANAN DALAM RAPAT KARANG TARUNA DESA SONOHARJO KECAMATAN WONOGIRI
}

\author{
Dika Saputra ${ }^{1}$ \\ ${ }^{1}$ Institut Agama Islam Negeri Surakarta \\ Email: dikasaputra7711@gmail.com
}

\begin{abstract}
Abstrak
Penelitian yang berjudul "Analisis Pelanggaran Maksim Kesopanan dalam Rapat Karang Taruna Desa Sonoharjo Kecamatan Wonogiri" ini bertujuan untuk mendeskripsikan bentuk pelanggaran maksim kesopanan pada rapat Karang Taruna di Desa Sonoharjo Kecamatan Wonogiri. Metode yang digunakan dalam penelitian ini adalah metode deskriptif kualitatif, yaitu dengan tahapan simak catat menggunakan alat perekam. Hasil penelitian ini menunjukkan bahwa dalam rapat karang taruna diketahui dalam teori pragmatik pada maksim penghargaan, maksim kecocokan, maksim kerendahan hati, maksim kebijaksanaan, dan maksim simpati yang sering digunakan adalah maksim penghargaan.
\end{abstract}

Kata kunci: Pelaksanaan maksim kesopanan, karang taruna, dan pragmatik.

\begin{abstract}
The study entitled "Analysis of Modest Political Violations in the Karang Taruna Youth Meeting in Sonogarjo Village, Wonogiri Sub-District" aims to describe the violation of modesty maxim at the Youth Organization meeting in Sonoharjo Village, Wonogiri Sub-District. The method used in this study is a qualitative descriptive method, which is with the stages of note taking using a recording device. The results of this study indicate that at the youth meeting known in pragmatic theory of maximal rewards, match maxims, maxims of humility, wisdom maxims, and sympathy maxims that are often used are the maximal rewards.
\end{abstract}

Keywords: Implementation of modesty maxims, youth clubs, and pragmatics.

\section{PENDAHULUAN}

Penelitian tentang maksim kesopanan merupakan salah satu penelitian yang termasuk kedalam ilmu pragmatik. Kajian maksim kesopanan biasa dikaitkan dengan konsentrasi cabang ilmu yang lainnya, misalkan sosiolinguistik serta ilmu psikologi. Wulandari, dkk. (2015: 101-102) menyatakan bahwa kesantunan berbahasa termasuk kedalam kajian ilmu pragmatik, sebab dalam berkomunikasi manusia harus mampu membangun citra baik terhadap lawan bicaranya sehingga mampu meminimalkan konflik.

Dalam menganalisis kesantunan berbahasa, untuk mengungkap wujud, fungsi dan strategi, dapat dilakukan dengan memahami makna dalam sebuah tuturan (Sadapotto, 2016: 548-549). Sedangkan Yunitawati (2014: 143) menyatakan bahwa pragmatik merupakan ilmu yang mempelajari tentang maksud penutur. Dalam berinteraksi di tengah masyarakat, seseorang menggunakan bahasa sebagai alat utama untuk berinteraksi. Proses berinteraksi menggunakan bahasa pastinya melibatkan penutur dan mitra tutur. Penutur dan mitra tutur sering kali mempunyai latar belakang yang berbeda, bisa karena jabatan, golongan, suku juga budaya. 
Manusia tidak akan pernah lepas dari kegiatan berkomunikasi, sedangkan bahasa merupakan bagian dari kegiatan berkomunikasi (Jumanto, 2017: 21). Ketidak lepasan bahasa disebabkan karena bahasa sebagai alat komunikasi antar manusia (Purwanti 2017: 2). Kesopanan seseorang dapat dinilai dari cara orang tersebut berkomunikasi dengan lawan tuturnya, hal tersebut yang membuat penelitian bahasa sangat menarik untuk dikaji. Rica dan Yupilarinda (2015: 272), menyatakan bahwa bersopan santun adalah faktor yang mendukung hubungan antara penutur dan lawan tutur atau pihak ketiga. Seseorang yang mempunyai tuturan yang baik dinilai sebagai seseorang yang memiliki sikap sopan. Penutur menuturkan suatu tuturan selalu mempunyai maksud yang ditujukan agar mitra tutur mengerti dan mampu menangkap makna apa yang dimaksudkan oleh penutur, Wijana (dalam Prayitno, 2011:29).

Kesantunan berbahasa menjadi aspek penting dalam berkomunikasi guna menciptakan komunikasi yang baik antara penutur dan mitra tuturnya (Kaka, 2017: 116). Prinsip kesopanan merupakan sebuah sistem hubungan antar manusia yang dibuat untuk memudahkan seseorang dalam berkomunikasi dengan manusia lain dengan meminimalkan konflik dan perlawanan yang sering terjadi antara penutur dan mitra tutur itu sendiri, Yule (2016:183).

Dalam hidup bermasyarakat, komunikasi merupakan sarana untuk bertukar informasi, bertukar pendapan atau pun menyampaikan gagasan. Dalam keadaan tertentu, sering kali terjadi pelanggaran prinsip-prinsip kesopanan. Setyawan (2015: 2) mengatakan bahwa pelanggaran prinsipprinsip kesopanan bisa terjadi karena adanya maksud dan tujuan tertentu tergantung situasi dan kondisi terjadinya tuturan tersebut. Tentulah perlu diperhatikan bagaimana sopan santun dan tata krama dalam kegiatan berkomunikasi yang dilakukan di lingkup masyarakat. Hal tersebut sebagai ajang untuk menghormati lawan bicara sehingga tidak terjadi kesalah pahaman dalam kegiatan berkomunikasi. 
Penelitian yang mengkaji mengenai maksim kesopanan pernah dikaji oleh Riska Prasetyarini (2014) yang mengkaji tentang prinsip kesopanan dalam rembug desa di Kelurahan Jatiroto Kabupaten Wonogiri. Penelitian tersebut mendapatkan hasil bahwa ditemukan 40 pelanggaran maksim kesopanan. Dalam penelitian itu juga dijelaskan mengenai sebab-sebab mengapa pelanggaran maksim kesopaan bisa terjadi, diantaranya karena adanya formalitas antara penutur dan mitra tutur, tingkat setatus sosial juga mempengaruhi, keadaan emosi mitra tutur, juga tujuan tutur penutur.

Berbeda dengan penelitian sebelum-sebelumnya, pada penelitian ini pembahasan lebih menitik beratkan pada bahasa yang digunakan para generasi muda yang dinilai harus memiliki sopan santun dalam hal berkomunikasi. Mengingat generasi muda sebagai generasi penerus bangsa, tentulah harus mampu menumbuhkan rasa simpati dan rasa saling menghormati yang tinggi. Terutama pada masyarakat jawa yang dikatakan memiliki sopan santun yang lebih tinggi jika dibandingkan masyarakat yang lain. Dalam forum diskusi, seperti halnya rapat, kesopanan sangat diperlukan mengingat rapat adalah forum pekumpulan yang melibatkan banyak pihak.

Penjabaran di atas yang membuat peneliti tertarik untuk melakukan penelitian tentang pelanggaran maksim kesopanan dalam rapat Karang Taruna Desa Sonoharjo Kecamatan Wonogiri ini. Untuk mengetahui apakah ada pelanggaran maksim yang dilakukan oleh peserta rapat tersebut dan apa saja faktor yang mempengaruhinya.

\section{METODE}

Penelitian ini menggunakan metode deskriptif kualitatif dengan menggunakan pendekatan pragmatik. Data dalam penelitian ini ialah tuturan yang telah direkam menggunakan alat perekam untuk selanjutnya dicatatat dan dilakukan analisi terhadap data yang diperoleh. Teknik pengumpulan data yang digunakan adalah dengan cara menyimak pembicaraan pada rapat dan merekamnya, selanjutnya dilakukan translite dalam bentuk tulisan untuk selanjutnya dianalisis. Analisis data pada penelitian ini disajikan dengan menggunakan proses triangulasi data yang meliputi tiga tahap. Tahap pertama yakni verifikasi data, penyajian data, serta klasifikasi data. Dalam verifikasi data, dilakukan peninjauan kembali terhadap data yang diperoleh, selanjutnya data disajikan, lalu diklasifikasikan menjadi beberapa kategori yang telah dibuat oleh peneliti.

\section{HASIL PENELITIAN DAN PEMBAHASAN}

Setelah mengkaji data-data yang telah diperoleh dari tuturan dalam acara rapat Karang Tatuna Desa Sonoharjo Kecamatan Wonogiri, ditemukan ada beberapa pelanggarakan beberapa prinsip kesopanan.

Bentuk Pelanggaran.

1. Pelanggaran maksim penghargaan

Tuturan (1):

Kadus : "Kita berharap kepemimpinan karang taruna tahun ini mampu lebih baik lagi, mengingat kepemimpinan tahun kemarin juga tidak begitu aktif karena mungkin ketua karang taruna kita akhir-akhir ini juga sibuk dengan pekerjaannya jadi tidak begitu maksimal dalam kegiatan karang taruna."

Penjelasan tuturan :

Kepala dusun pada saat memberikan sambutannya mengatakn ketua karang taruna yang dulu kurang aktif dalam kegiatan karang taruna karena terlalu sibuk dengan pekerjaannya. Lantas menghimbau kepada keanggotaan yang baru agar lebih aktif dalam semua kegiatan yang diadakan karang taruna.

Faktor : 
Kepala Dusun mengatakan hal demikian sebagai kritik atas kepemimpinan karang taruna yang dulu dan sebagai penggugah semangat kepada anggota karang taruna yang baru agar lebih meningkatkan kinerjanya dalam segala kegiatan yang dilakukan di dalam program kerja yang telah dibuat.

tuturan tersebut telah melanggar maksim penghargaan sebab telah menyindir kinerja ketua karang taruna yang dulu yang kurang baik.

Tuturan (2):

Kadus: "Sebenarnya karang taruna itu kan juga punya grup WhatsApp, tapi kok kenapa saya tidak dimasukkan, adminnya kemana saja? kan seharusnya saya dimasukkan, biar tau apa saja kegiatan yang kalian lakukan."

Penjelasan tuturan :

Kepala Dusun mengatakan bahwa dirinya tidak dimasukkan dalam grup yang telah dibuat oleh karang taruna, tuturan ini ditujukan untuk pengelola grup WhatsApp yang tidak memasukkan dirinya.

Tuturan tersebut melanggar maksim penghargaan, sebab dalam tuturan "Adminnya kemana saja?", kadus menyindir anggota yang memegang kendali media sosial tersebut.

Faktor : Kepala Dusun mengatakan hal tersebut agar dirinya mengetahui dan dapat memantau kegiatan yang dilakukan oleh para pemuda, mengingat pemuda juga termasuk tanggung jawab beliau.

Tuturan (3) :

Arif : "Opo iso nulis Aris kui, nganggo pendamping po piye?"

(Apa bisa nulis Aris itu?, Pakai pendamping aja gimana?)

Penjelasan tuturan :

Pada saat pemilihan dilakukan dengan menuliskan suaranya pada selembar keras, lalu dimasukkan kedalam sebuah box untuk selanjutnya dihitung. Saat aris maju untuk menuliskan nama calon ketua pilihannya Arif mengatakan apakah Aris bisa menulis untuk memilih ketua karang taruna.

Tuturan di atas menyatakan bahwa Arif melanggar maksim penghargaan dengan mengatakan bahwa Aris tidak bisa menulis, bahkan harus memakai pendamping untuk membimbingnya menulis nama pilihannya.

Faktor : Arif mengatakan hal demikian sebab Aris adalah teman akrabnya dan untuk mencairkan suasana rapat agar tidak terlalu tegang.

Tuturan (4) :

Gunawan : "iki entuk suworo siji iki mesti wonge nulis jenenge dewe iki"

(Ini mendapat suara satu ini pasti orangnya nulis sendiri ini).

Penjelasan tuturan :

Gunawan mengatakan kepada salah satu anggota yang hanya mendapatkan satu suara bahwa dia menuliskan namanya sendiri ketika pemilihan berlangsung.

Dalam tuturan ini, gunawan telah melanggar maksim penghargaan sebab menuduh bahwa orang yang bersangkutan memilih dirinya sendiri agar menjadi ketua karang taruna.

Faktor: Gunawan bermaksud bercanda untuk sekadar mencairkan suasana rapat.

Tuturan (5) :

Yoga : “Ojo Gunawan sing dadi ketua, rusak kabeh mengko.” (jangan Gunawan yang jadi ketua, rusak semua nanti).

Penjelasan tuturan : 
Yoga mengatakan, jika seandainya Gunawan menjabat sebagai ketua karang taruna, maka karang taruna yang dipimpinnya akan rusak dan tidak berjalan dengan semestinya. Tuturan itu disampaikan di tengah-tengah rapat sedang berlangsung ketika sedang dilakukan perhitungan suara.

Dalam tuturan di atas, Yoga melanggar maksim penghargaan atas Gunawan, sebab telah terkesan meremehkan kinerja Gunawan.

Faktor : Perkataan Yoga mengenai Gunawan adalah perkataan gurauan sedang memang Gunawan tidak banyak mendapatkan suara dari para pemilih.

Tuturan (6) :

Muhamad Faisal : "Masa rapat snack e gur kaya ngene?"

(Masa rapat snacknya Cuma kaya gini).

Penjelasan tuturan :

Ari mengatakan bahwa hidangan yang diberikan saat acara rapat tersebut kurang sesuai dengan seleranya, tuturan tersebut disampaikan dihadapan sebagian peserta rapat yang ada di sekitarnya.

Pada tutran di atas, Muhammad Faisal telah melanggar maksim penghargaan, sebab tidak menghargai apa yang sudah dihidangkan pada acara rapat kang taruna tersebut.

Faktor : Muhammad Faisal mengatakan demikian sebab sebagai wujud protes terhadap panitia penyelenggara rapat yang menurutnya tidak pantas memberikan hidangan seperti yang telah disediakan.

2. Pelanggaran maksim kecocokan

Tuturan (1) :

Ketua : "Ini mau pemilihan ketua bagaimana dengan voting atau dengan musyawarah?"

Ari : "Dengan musyawarah saja".

Ketua : "Kalau musyawarah pasti butuh waktu lama".

Penjelasan tuturan :

Dalam acara rapat reorganisasi keanggotaan karang taruna, ketua memberi pilihan apakah dilakukan voting ataukah musyawarah. Ari memilih untuk dilakukan voting saja, akan tetapi mengingat waktu yang sangat sempit, ketua tidak setuju dengan ari karena berpendapat bahwa voting adalah cara terbaik untuk memilih ketua yang baru.

Dalam dialog ini, ketua melanggar maksim kecocokan karena dia tidak sependapat dengan ari mengenai metode yang dipilihnya.

Faktor : Ketua melakukan hal tersebut demi kelancaran jalannya rapat.

Tuturan (2)

Kadus : "Sebaiknya segera dipilih siapa saja yang menjabat sebagai bendahara, sekretaris dan bagian-bagian yang lain".

Ketua : "Minggu depan saja kita adakan rapat lagi untuk menentukan itu semua".

Penjelasan tuturan :

Kepala dusun menyarankan agar segera dibentuk untuk menentukan kepengurusan pada malam itu setelah ketua yang baru sudah remi dipilih. Akan tetapi ketua tidak menghendaki hal tersebut dan memilih untuk melakukannya pada pertemuan selanjutnya. Dalam tuturan ini, ketua melanggar maksim kecocokan karena berbeda pendapat dengan kepala dusun.

Faktor : Ketua memilih melakukannya minggu depan sebab sudah melihat peserta rapat sudah tidak konsen mengikuti jalannya rapat pada malam tersebut serta mengingat hari sudah terlalu larut malam.

Tuturan (3) :

Mei Purnomo : "Mas Faisal bisa menjadi pengurus ya? Kan tidak kemana-mana. 
Muhammad Faisal: "Sorry mas, saya sekarang sibuk kerja, jadi tidak bisa fokus di rumah".

Penjelasan tuturan :

Tuturan di atas disampaikan Muhammad Faisal ketika misalkan diminta untuk menjadi pengurus karang taruna, sebab para peserta rapat menilai bahwa dia berdomisili di rumah dan tidak banyak meninggalkan desa, namun dia menjawab dia sibuk karena kerja.

Tuturan yang disampaikan Muhammad Faisal sebenarnya adalah bentuk penolakkannya karena ditunjuk sebagai pengurus, hal tersebut tentu melanggar maksim kecocokan.

3. Pelanggaran maksim kerendahan hati.

Tuturan (1) :

Andi : "Nek ora enek Arif ora dadi pokok e."(kalau tidak ada Arif tidak akan jadi ini)

Arif : : Yo jelas no." (ya jelas dong)

Penjelasan tuturan :

Arif mengatakan dan mengiyakan perkataan Andi bahwa kalau tidak ada dirinya pasti acara tersebut tidak berjalan dengan lancar.

Tentu hal tersebut telah melanggar maksim kerendahan hati, sebab Arif mengakui bahwa dirinyalah yang membuat acara tersebut menjadi sukses.

Faktor : Perkataan Arif sesungguhnya adalah cara dia dalam merespon apa yang dikatakan Andi sebagai sebuah candaan untuk sekadar mencairkan suasana.

4. Pelanggaran maksim kebijaksanaan.

Tuturan (1)

Mei : "Taufik nanti bisa membuat daftar nama-nama anggota ya, saya tunggu."

Penjelasan tuturan :

Tuturan di atas disampaikan dengan maksud memberi perintah kepada Taufik dan tidak mnggunakan kata minta tolong ataupun menyebut Taufik dengan sebutan mas sebagai penghormatan kepada anak laki-laki pada masyarakat jawa.

Hal tersebut tentu telah melanggar maksim kebijaksanaan, seharusnya Mei bisa memakai kata-kata yang sedikit lebih sopan supaya Taufik menjalankan tugasnya dengan senang hati.

Faktor : Tuturan tersebut diucapkan oleh ketua kepada bawahannya. Umur Taufik pun juga sedikit lebih muda jika dibandingkan dengan Mei.

5. Pelanggaran maksim simpati.

Tuturan (1) :

Nopi : "Mending orasah mangkat yuk, gur oleh suara siji".

(Mending tidak usah berangkat yuk, Cuma dapat satu suara).

Penjelasan tuturan :

Tuturan di atas dikatakan Nopi ketika rapat telah selesai. Ia menyindir Ayuk yang hanya mendapatkan satu suara sehingga tidak terpilih menjadi ketua karang taruna yang baru. Hal tersebut membuat Nopi melanggar maksim kesimpatian.

Faktor : Tuturan tersebut diucapkan Nopi dengan maksud bercanda kepada Ayuk yang juga kerabatnya.

\section{SIMPULAN}

Setelah melakukan penelitian terhadap sampel yang sudah tersedia dan disiapkan sebelumnya, dapat disimpulkan bahwa ada terdapat beberapa pelanggaran maksim yang terjadi pada acara rapat Karang Taruna yang dilaksanakan pada tanggal 5 Juni 2019 tersebut. Pelanggaran maksim tersebut 
yakni pelanggaran maksim penghargaan, pelanggaran maksim kecocokan, kerendahan hati, kebijaksaan serta kesimpatian. Kebanyakan pelanggaran maksim terjadi pada maksim penghargaan.

Pelanggaran maksim tersebut terjadi karena banyak faktor, seperti suasana hati penutur maupun mitra tutur, kondisi emosi penutur maupun mitra tutur, juga hubungan antara penutur dan mitra tutur. Dalam ranah pemuda-pemudi memang banyak ditemukan pelanggaran maksim yang disebabkan oleh faktor hubungan antara penutur dan mitra tutur yang erat dan akrab. Sehingga pelanggaran maksim kebanyakan terjadi dengan tujuan sebagai bahan candaan antara penutur dan mitra tutur. Namun banyak juga pelanggaran maksim dengan tujuan untuk membuat kondisi atau merubah perilaku seseorang agar jau lebih baik lagi, dalam analisis data di atas, misalkan saja tuturan Kepala Dusun dengan para anggota karang taruna, hal tersebut diakukan untuk membuat organisasi Karang Taruna menjadi lebih baik lagi.

Mengingat berkomunikasi secara langsung memerlukan etika prinsip kesopanan, sangatlah dianjurkan untuk menggunakan kata-kata yang sopan agar mitra tutur tidak merasa sakit hati ataupun tidak timbul ras benci terhadap penutur. Terlepas dari konteks candaan yang sering melanggar maksim kesopanan, para pemuda haruslah menggunakan bahasa yang sesuai dengan prinsip kesopanan agar bisa menghormati orang lain sebagai mitra tuturnya.

\section{DAFTAR PUSTAKA}

Jumanto. 2017. Pragmatik: Dunia Linguistik Tak Selebar Daun Kelor Edisi 2. Yogyakarta: Morfalingua.

Kaka, Pelipus Wungo. 2017. "Analisis Terhadap Kesantunan Tindak Tutur Direktif Guru dalam Pembelajaran di SD Inpres Bajawa VI Kecamatan Bajawa Kabupaten Ngada”. Jurnal Ilmiah Pendidikan: 4(1): 114-127.

Leech, Geoffrey.1983. Principle of Pragmatics. New York: Longman.

Nadar, F. X. 2009. Pragmatik dan Penelitian Pragmatig. Yogyakarta: Graha Ilmu.

Prayitno, Harun Joko. 2011. Kesantunan Sosiopragmatik. Surakarta: MUP Universitas Muhamadiyah Surakarta.

Purwanti, Ni Made Anggun, I Wayan Rasna, dan Ni Made Rai Wisudariani. 2017. "Prinsip Kesantunan pada Talk Show Rumpi (No Secret) di Trans TV". E-Journal Universitas Pendidikan Ganesha Jurusan Pendidikan Bahasa dan Sastra Indonesia 6(1): 1-10.

Rica, Yabanci Dil Olarak Türkçe Konuşucularinin dan Yupilarinda Kullandiği Nazaket Stratejileri. "Politeness Strategies Used by L2 Turkish Speakers in Making Request". International Journal of Language Academy, 3(4): 207-294.

Sadapotto, Andi dan Muhammad Hanafi. 2016. "Kesantunan Berbahasa dalam Perspektif Pragmatik". Proceendings The Progressive and Fun Education Seminar. Sumatra Utara, Agustus 2016.

Setyawan, Agustinus Hary. 2015 "Prinsip-Prinsip Kesopanan pada Rapat Politik Margaret Thatcher dalam Film The Iron Lady". Jurnal Sosio-Humaniora,6(1): 1-22.

Wulandari, Agustina, dan Ngusman. 2015. “Tindak Tutur Ekspresif Maryo Teguh dalam Acara "Golden Ways". Jurnal Bahasa, Sastra, dan Pembelajaran, 2(1): 99-113. 
Yule, George. 2006. Penelitian Kualitatif. Surakarta: UNS Press.

Yunitawati, Azizah Malikha, Abdul Ngalim, dan Atiqa Sabardila. 2014. "Penyimpangan Prinsip Kerja Sama dan Prinsip Kesopanan Wacana Kartun pada Buku Politik Santun dalam Kartun Karya Muhammad Mice Misrad”. Jurnal Penelitian Humaniora, 15(2): 141-154. 